\title{
Existentialism and Death Education in Anime:
}

\section{A Micro and Macro Analysis of Cells at Work!}

\author{
Irene Iwasaki
}

\author{
Volume 2, Pages 155-184
}

\begin{abstract}
As the 2020 global pandemic has demonstrated with new force, we continue to struggle with managing primal, existential fear, even during the ongoing struggle to understand and combat a deadly infectious disease. As this paper reveals, multimedia popular culture texts can provide us with tools, knowledge, and avenues to help us better express, empathize, and educate one another during trying times. In particular, this paper aims to form part of a larger discussion on how we can better face the task of looking at death during a moment of human history where doom may seem ubiquitous. Although it is not possible to separate ourselves from our dependence on information that links us as individuals to the outside world, we can engage with media that provides knowledge in a more palatable or entertaining way and in so doing, support the development of better coping skills for apprehension about an unknown tomorrow. This paper analyzes the 2018 Cells at Work! as an example of anime that is both educational and entertaining, and discusses its implications for terror management and the promotion of well-being.
\end{abstract}

Keywords: Educational anime, existentialism, pandemic, terror management, Cells at Work!

Author Bio: Irene Iwasaki is an instructor of Japanese History, Japanese Society, and Japanese Pop Culture at Alexander College in Burnaby, B.C. Canada. She was previously a university instructor of Japanese Studies and ESL in Osaka, Japan. She has an MA in Japanese Studies from the University of Sheffield, an MEd in Educational Technology from UBC, an MEd in Teacher-librarianship from the University of Alberta and is currently working on a $\mathrm{PhD}$ in Creative Writing from Bircham International University. Her research interests lie in using media and visuals to enhance motivation in learning, especially for students whose first language is not English. She has written several academic articles as well as textbooks for ESL.

This work is licensed under a 


\section{Introduction}

With the current capacities of digital technology, today we can easily scoff at earlier historical moments where it could take years to deliver information, messages, or stories across distances, whether countries or continents. Still, however quickly we may pass along our ideas and information with new media today, the overall condition of humans and their environments leads to an ongoing question: do we actually feel safer and happier than our predecessors did, thanks to the amount and speed of information we now have access to, or do we live with as much or even more angst and anxiety about the future than before? Most readers will have their own thoughts and even experiences regarding such a broad, anecdotal start, but in short: existential fear is part of being human. We cannot avoid it, but we can manage it so that it does not dominate our lives, and one way of doing this is to discuss death and our feelings about it openly.

The following paper will elaborate on these ideas through an analysis of the anime Cells at Work!, a particular popular culture text that uses an entertaining approach to exemplify the complexities of a living organism that is constantly being threatened with ailments that may lead towards inevitable death, either slowly or quickly. As this paper demonstrates, Cells at Work! and its premise, characters, and story can help springboard productive thoughts and discussion not only of sickness and health, but also about death itself. Moreover, this anime does so in terms that can encourage reflection on the choices we make that define our morality and mortality. 


\section{Cells at Work!: Premise and Plots}

When Akane Shimizu was in college studying to become a manga artist, her younger sister, a junior high school student, needed help understanding her biology homework. Shimizu attempted to explain the terminology and concepts to her sister with illustrations, even developing them into characters and scenarios. While doing so, Shimizu realized that she had a great idea for her graduation project, which indeed ended up winning an award and an offer for publication that later became the manga Cells at Work! $!^{1}$ Then after the manga became a success, it was adapted into an anime series for Japanese TV and translated on Netflix for international audiences in 2018.

The premise of Cells at Work! is to show how the human body functions, particularly how cells fight or succumb to a variety of conditions or illnesses. In depicting this, the show is both entertainment but also educational. At its core exists a version of the classic existential story: good (here, human cells) vs. bad (here, organisms such as germs and viruses), a clash that in this show leads to suffering and life-threatening scenarios. The denouement of each episode is marked with momentary celebration, but there is also the impending doom to be continued in the next episode, creating a pattern that mimics human behavior or biological cycles as well. The repeated occurrences of sickness that humans must deal with, along with the threat or at least thoughts of death, is not unique to Cells at Work!, but instead "Death is an inherent part of many anime plots. Depending on the nature of the character, it can be interpreted in different ways: as a main theme, as inevitable as fear, as a loss as the result of a lifetime as a mere moment. Each new character treats its own way, bringing in the anime its own unique philosophy." 2 Death in anime, then, is meant to be a 
reflection of this fundamental reality in viewers' own lives, even if just depicted or labelled as being fantasy and fiction in particular shows.

In international categorizations of animation, Japanese anime may be labelled as a single genre. Within anime, though, there are multiple genres and sub-genres, which means that some anime such as Cells at Work! fit or cross over into more than one genre, sometimes in terms of the desired viewers' age group or gender as well as content and style. In this particular case, Cells at Work! is primarily a visual fantasy, but in parts those visuals are layered over with non-fictional narration that explain science, medicine, and the human body factually. This anime could also be considered science fiction or dystopian because of its post-apocalyptic (i.e., post-infection) imagery. Likewise, it is also a thrilling drama that sometimes plays out as a mystery to be solved (or cured) and is full of action with its many fight or flight scenes. Its suspenseful content is juxtaposed with comic-relief too, so that it could also be categorized as comedy or even as a romantic comedy because of the relationship that grows between main characters Red Blood Cell and White Blood Cell.

This genre-blending makes Cells at Work! appealing for many different audiences, but even beyond that, perhaps there is always wide appeal when the content concerns life and death, and more than in just the context of patriarchal samurai suicides, war, war games or war crimes. Instead, a broader, more general conception of death is a topic that is of interest to viewers regardless of age, gender, race/ethnicity, socio-political status, health, and other axes of identity and experience. For example, Miyazaki's Ponyo, with its child-protagonist (Sosuke) and child-creature-protagonist (Ponyo), depicts its young characters surrounded by threats of death on land and sea, 
yet this story is intended for an audience that includes both young and old alike. In another example, Japan Sinks 2020 also presents an existential story set on a threatened and threatening land and sea, with the addition of comparatively diverse characters such as the Filipina protagonist Mari and her children, the transgender Kite, the physically disabled scientist Onodera, and the displaced Daniel who lost his family in the former Yugoslavia, among others meant to represent minority groups and their struggles for survival. There is also Demon Slayer (which by the end of 2020 had grossed more than any other film in Japanese history3), which follows more than just the story of slaying demons (here, former humans now devoid of humanity) and instead also parallels realities that will be more familiar to readers by depicting the challenges of caring for family in desperate times, the hunt for a cure for a virus/curse, and a setting where power comes from the ability to breathe. Put differently, life and death stories naturally concern a wide range of audiences, and anime as a genre is not averse to portraying death, even graphically. This approach is "not to cover one's eyes from the reality of death, but to enjoy the world as it is presented to us in all its aspects. This procedure is alien to mainstream European philosophy and psychology... (but) at various stages of Japanese history it was felt necessary to educate people in confronting the inevitability of corporeal death."4

This paper builds from these considerations of genre and subject matter to reflect on the fact that we are currently living during a time when the world could benefit from looking at death through a similar lens to the one(s) that have been developed in anime. 


\section{Cells and Self}

The entire story of Cells at Work! takes place inside a human body where each cell looks and acts like a human being, each with a style and personality that matches the particular cell's job. The human body itself does not become a character, but instead serves as the show's setting. The main characters are a single red blood cell and a single white blood cell, and the anime follows them confronting a different ailment/antagonist each episode. Introduction or exposition sets the stage for each episode's upcoming battle, followed by rising action as the story progresses and then climaxes in the ultimate theme of defeat and/or survival of various cells. Throughout, scientific or medical information is explained factually and either narrated by characters or visually imposed over the main animation with written definitions or graphs sharing the mise-en-scene.

The characters in Cells at Work! both are and are not human; that is, each cell

character looks, acts and speaks like a human with all associated thought processes and fallibilities, but technically are just representing individual cells that make up a single, "real" human (who himself never actually becomes a developed character in the show). Although some of the cell characters are quite complex, they do not have "real" names, and are instead called by their medical terms. The main character here is Red Blood Cell and her partner is White Blood Cell. Red Blood Cell has a job as a delivery person who carries boxes filled with oxygen to her customers, who are all called Mr. or Ms. Cell. When the anime begins, Red Blood Cell is a rookie and sometimes has trouble finding the right direction to go or finds trouble along the way, such as germs, bacteria, viruses, or other cells in distress. Over the course of the show, her personality develops and her 
experience grows until eventually she becomes a mentor to other red blood cells. White Blood Cell, sometimes along with background characters such as the B-cells or the army of Killer-T cells, appears in each episode to help Red Blood Cell fight against various antagonists or figure out what the existing health problems are and how to cure them.

In many ways, then, Cells at Work! is premised on and depicts never-ending existential dread. There are always new threats that make Red Blood Cell anxious and push her to make life-altering decisions, but as the show demonstrates, this is all part of the cells' jobs to provide aid and keep their shared living environment safe and peaceful together.

One reason why Cells at Work! is so diverting is because the cell characters are manifestations of the realities and vulnerabilities of our own human bodies as well as the greater environments that our bodies exist in. The characters and storylines in this anime encourage viewers to improve their health and well-being while also highlighting the importance of working together for the best possible outcome for the places in which we live. This is another common characteristic of the larger genre of anime, as "Kyara (Japanese anime characters) exist as playful objects for consumption not only of aesthetic and other associated functions, but of the specific messages their producers promote." $5 \mathrm{On}$ a micro level within this show, the characters in Cells at Work! are representations of the billions of cells that are alive (and even some of those that are dead) within viewers' own human bodies. On a macro level, these anthropomorphized cells represent characters in greater society, even functioning as they do on a national or global level with incoming "threats" to the domestic body. The good cells are social agents of change, responding to emergency situations where backgrounds and props sometimes mirror socio-political, 
economic, or physical catastrophes recognizable to viewers. In various episodes, the body as a setting often looks defeated or decimated, as the show's viewers will recognize from footage or depictions of real-world sites in the aftermath of war, natural disaster, or other catastrophes. However, through its recognizably anime art style and its empathyinducing approach, Cells at Work! pleads with us as viewers to be aware of our health and the choices we make in exposing ourselves, others, and our environments to potential danger, whether through action or inaction.

As Cells at Work! is set within a human body that houses the entire story, all of the action is contained within this body/world, and existential fear comes into play when the cells within are not immediately able to defend themselves from threats, such as foreign organisms. An exception to this is in an episode about auto-immunity, where the body attacks itself (similar to civil war or a nation-state that is over-policing or even makes threats to deploy its military against its own people). The setting might be just a work of the imagination as communicated to viewers using computer graphics, but our "real" physical bodies and political bodies do run in comparable ways. Thus, these storylines serve as a reminder to take care of ourselves and think about how the choices we make affect the communities and societies that we are connected to.

In this show, another significant message is that others can be affected by our actions positively or negatively even if those individuals are physically at a distance from the site of the choice. This is the way that the cell characters work: they may be analyzed individually, but they function best with other cells in ongoing mutual relationships: "in Cells at Work!, a body is an equitable, hard-working country, with a strong conception of unity and community." 6 Whether on an individual micro level or a 
wider macro level, this encourages viewers to think about the necessity of cooperation for the greater good.

\section{Imagery and Metaphors}

In this anime the viewer, with sudden microscopic vision, can see and experience an individual human body as an entire functioning world, as "Cells at Work! gives viewers a look inside the daily lives of the cells inside us, reimagining the tiniest units of life as heroes and villains and the human body they inhabit as a sprawling urban environment. At this level, even the smallest scratch to the skin's surface can cause catastrophe down below."7 The cause-and-effect destruction of cells and tissue is magnified because it is shown as the death of individual characters that viewers become attached to, or even identify with, while watching. As each cell is anthropomorphized to look and act like a whole individual human on its own, the emotions of the viewer become much more involved than if analyzing live, or dead, "real" cells through a microscope. This is an example of a hyper-animated reality, but also mirrors the way complex organisms think, feel or function. For instance, the dehydration of cells is shown as happening when the Mr. and Ms. Cells start dying of thirst, and lack of nutrition is represented as the failed delivery of picnic baskets filled with food. When animated and depicted using colorful characters, these become amusing scenarios, but they are also reflective of the fact that many people around the world do become dependent on comparable essential and emergency services during events such as the ongoing pandemic. In particular, these scenarios from Cells at Work! also demonstrate how failing to take care of vulnerable sectors can become detrimental 
to the well-being of the whole.

The fact that death already exists within the human body is also a constant in Cells at Work!, as shown through a constant conquering array of germs, diseases, bacteria, and viruses. Some of these antagonists are shown as greenish zombie-like creatures who are both on the brink of death as well as contagious. They are at once enemies but also an integral part of the biosphere, thus reflecting the idea that: "we become zombies because we are zombies." 8 Learning to accept that we are all at least partially infected could help promote empathy and responsibility to care accordingly for our fellow organisms who may be more or differently affected. Whether portrayed as comedic or horrific in different media, these scenarios depict the truth that as organic creatures, we are vulnerable to sudden or untimely death, especially when - like in Cells at Work! - we cannot see what is happening within our physical bodies. That is, we are surrounded by death on the inside as well as the outside of our bodies, but as humans who strive for youth, beauty, health, and vibrancy in cultures obsessed with these things, oftentimes we are not able to face this truth easily. Here is where "The zombie functions as a critical circuit-breaker. Publicly, the zombie's circuit-breaking force might be detected in zombie-cinema, which has effectively produced new interventions for thinking how people identify with media images."9 In zombie/monster/virus cinema, the distinctions between micro and macro can be considered blurred, or possibly absurd, but in Cells at Work!, the show communicates that the size of the organism is not as relevant so much as the fact that the micro and the macro are equally vulnerable. Here, when a single cell dies, a character dies. In the viewers' own world, when cells in the body are affected by a virus that has come into their territory, the body becomes ill; 
when social actors both individual and institutional/political do not work together to limit viral spread, then the illness of individual bodies can quickly become a pandemic.

In this way, death is not just something that we reach or mark at the end of our life, but instead, is always already a part of us: "germs, and death, will always be with us. There is no ritual that eliminates them or even ensures that we have any space between us and them."10 By acknowledging this, we could learn to be sensitive to others' vulnerability and fragility or even see beauty in the temporariness of life, whether big or small, local or global. In this way, Cells at Work! offers an effective visual reminder that the stages of life and death are continuously playing out within our very bodies, and if that fact can be internalized, then facing existential challenges in the outside world might be done with more confidence as well as compassion.

The body is much more than a temple (or a shrine), and in this anime in particular, "the industrial nature of the backgrounds in Cells at Work! is a unique take on humans' internal physiology. Scenery is primarily hallways, tunnels, large mall-like open areas (sans stores), roads, and rooms. Resources like oxygen are labeled as boxes, and nutrients carried by red blood cells are baskets of fruit and bread... signs are placed everywhere to tell the audience that they are looking at the lungs, the kidneys, or the lymphatic vessel." 11 That is, while Cells at Work! is a visual and educational delight, it also shows viewers quite literally that we are all in need and dependent on constant nutrition, oxygen, circulation, and that without them, fundamental systems like our cells and cell walls can quickly break down. Cells at Work! also offers a frank, colorful look at some of the human body's own less-than-desirable functions and fluids, which functions as a fun but effective way of taking down glamorous idealizations of the 
human body by showing that on the inside, all are equally beautiful and/or ugly. Bengtson reflects on the need for students in particular to be exposed to this reality: "We might refer to this learning as the moments of 'little deaths' in education, which can be brought forward by an experience of, or reflection on, what it means to be oneself or a distinct self. The moments of little deaths, highlight the vulnerability of the learning subject."12 These "little deaths" should not only rise as the occasional teachable moment, but also, instead, be incorporated into the curriculum so that these ideas become as familiar and accessible as alphabets or counting systems (which, unlike death, are only man-made or artificial systems anyway). Learning about death naturally should be a part of curricula because bodily functions, failings, and even death are natural and unavoidable phenomena. In this way, Cells at Work! can easily function as an example of death edutainment, since it merges visual fantasy with the hardcore reality of death while being a medium that allows viewers to zoom in and thus learn the intricacies of the human body.

\section{Implications for Education}

Most viewers today will be bombarded with cultural and media messages in which youthfulness and surface-level beauty are valued while aging and sickness are feared. But hiding, covering up, or trying to avoid our natural processes of aging and sickness is only covering up our existential fear. Cells at Work! is prime edutainment that brings the inner workings of our bodies to the spotlight and displays graphically that, at our cores, we are all susceptible to the same ailments that threaten the human mind and body alike. Seeing "the fluids in our bodies remind(s) us of our status as creatures, and if we can overcome our denial of death and our associated creatureliness, we might 
engage in a different ethics." 13 That is, if we can accept the fact that illness has always and will always live with us and within us, perhaps we could more easily move forward in our management of existential fear and the conditions or fallacies (i.e., anxiety, depression, blame, conflict, and more) that accompany it.

Educators can work with media to communicate this to students in a less harrowing way, and anime itself is a prime candidate because it "is at once a uniquely Japanese art form and a valuable classroom tool. Students are often already invested in or excited about the genre, having encountered it in their everyday lives... Even for those students who have not previously encountered anime, the perceived accessibility of animated films and the exciting technology used for creating animations can serve to invest students in the material."14 Because anime is a fun and visually pleasing medium, even its depiction of the grotesque can be positively engrossing, and therefore, can offer an easier pathway into learning about the challenging topic of death. Cells at Work! is an anime created for both enjoyment and learning, as corroborated by various reviews: "there is not a moment in this anime left untouched by an educational sign,"15 it is "scientifically accurate,"16 and "the progression of the episodes is actually very reminiscent of how you teach biology/physiology/immunology."17 Thus, Cells at Work! could serve as a fun supplementary material in science class or be assigned as pleasurable homework, since it covers topics related to the human body, sickness, and healing as well as death. It can also introduce or act as an effective review of terminology, and the series does build upon ideas and terminology similar to how educational curricula is planned. Since it explains the structure and functions of our anatomy visually, these colorful anime-style images may also help boost memorization 
or recall of core concepts.

The added layer of vulnerability to these cell characters helps give a deeper education about the complex emotions surrounding suffering and death. Beyond the courses outlined above, then, this means Cells at Work! could also be suitable for a humanities class where discussions of war and inhumanity are constant. In subjects where there is content regarding death, especially untimely or tragic, but where victimized individuals and their bodies may not be addressed as much more than with general death counts, social-emotional development may be missing. To counter this sadly-common shortcoming, stories such as those in anime could be used to supplement hard topics in the humanities, a field whose very goal is to make our world a better place through awareness and management (of our emotions, thoughts, and actions, as well as of our technology) for the sake of the greater good. Cells at Work! shows what happens when we lose that management, since "by presenting the smallest areas of the human body as massive cities, every single problem becomes an apocalyptic-level catastrophe."18 Social, political, and/or economic chaos can mirror biological chaos, and it takes constant effort from all levels and parts to maintain calm, order, and prosperity for the whole. Educators can use edutainment like Cells at Work! to show in a fun and accessible way that "in order to maintain overall health, it's imperative that order is maintained... rather than profit, the goal is health and wellbeing for the body itself [which is] the parallel upon which Cells at Work! situates itself."19 In other words, discussions of the show's episodes or scenarios can be relevant to help springboard discussions in science, the social sciences, and the humanities alike, where issues and topics such as the Covid-19 pandemic have worked their way into the curricula. 
Iyashikei, which means healing, is a category or sub-genre of anime that attempts to heal or emotionally soothe the viewer. Iyashikei anime usually has more mundane plots, flatter characters, and a more sombre mood than Cells at Work!, but because the main character Red Blood Cell goes through the motions of her repetitive job (delivering oxygen), she can be considered, both literally and figuratively, a healing character. This is particularly relevant now as "so many of us feel worried and lethargic, completing even the most basic of tasks can be a challenge. Watching a fictional character do chores seems boring in theory, but iyashikei sparks the human need for completion and, right now, serves as one of the best forms of comfort." ${ }^{20}$ Although the plot of Cells at Work! often illustrates chaos when there is a sudden attack of a new ailment, it could still be considered iyashikei because there is also resolve (i.e., physical healing) to each episode, which means that the viewer can leave afterward with a sense of calmness. Healing anime can be a good supplement for students, especially during the pandemic when young people may feel particularly isolated or disillusioned about the future. Cells at Work! can also offer a sense of normalcy in an unprecedented time, when lives at school have been interrupted suddenly; viewers may be comforted seeing that this is paralleled in the cells' lives as well.

This need seems clear, as the demand for anime through streaming services jumped $50 \%$ in 2020 and the rate of new anime viewers grew by $30 \% .{ }^{21}$ Given this, it does not seem far-fetched to posit that the increased consumption of anime during the Covid-19 pandemic is not only filling an increased demand for home entertainment, but also may be helping to fill an emotional void that popular culture such as relevant characters and storylines can offer. On a more meta level as well, the rising popularity of 
anime may also be preventing the spread of disease since "anime has an advantage over live-action content because it doesn't require actors and crew to expose themselves to virus contagion."22 In both cases, anime is a media form that can promote safe work spaces and streaming platforms like Netflix provide viewers with more choice and convenience of what shows can serve as a sort of visual comfort food.

\section{Implications for Terror Management}

Building from ideas gestured toward in earlier sections, this section discusses terror management theory and ways in which additional, expanded education can help mitigate terror. To begin with, in relation to death, "terror is the natural and generally adaptive response to the imminent threat of death... This realization threatens to put us in a persistent state of existential fear." ${ }^{23}$ However, knowledge and education can be means of mitigating and lessening terror about topics such as death. In particular, the purpose of death education is not to highlight the morbid or to increase dread, but instead, to provide students with practical knowledge as well as coping mechanisms towards this inevitable biological phenomenon.

Whether added as part of in-class content, a selection of extra-curricular content, or as homework, existential and educational anime such as Cells at Work! could help to teach this truth gently. Death may be the ultimate fear, but it must be faced directly in order to be managed. After all, "knowing that one is destined to die, coupled with an intense desire to go on living, creates in the human animal an acute potential for existential terror... if humans were to experience this existential fear unmitigated it would interfere with many effective forms of thought and action.”24 To manage 
existential terror, educators must present students with truth but also consider the emotional impact(s) of that information. One way of doing this is to approach death in a manner that will not cause a fight or flight reaction.

For instance, facilitating death education with humor and curiosity can soften the topic. Graphic anime in particular can help students "reimagine the body during this time of disaster... [and] Cells at Work! does just that, and it may be the perfect balm in an era where coronavirus has made bodies so frightening and unpredictable.”25 Entertaining death education may ease fears that young people have of their bodies or society during a pandemic. To manage fear and anxiety of death, educators can help students to accept that death is just the simple end of life and breath; attempting to shield them with lessons that avoid talk of death is to deny or deprive them of the truth about this inevitability, which would be an anti-educational move. Gentle, educational reminders of mortality can increase accessibility to thoughts about death in a positive way. ${ }^{26}$ As a result, if students can learn about death head-on, then they may develop more control over many of the negative thoughts and anxieties that accompany death.

Another way of denying death or refusing to face one's existential fear on the topic is through the action of avoiding a health check - including medical tests or vaccines - and/or the reluctance to seek counselling. Education, however, can help bridge the gaps between patients and medical professionals who may be regarded as harbingers of death news, and "Cells at Work! serves as a good introduction to this greater medical world, and those armed even with a little of this knowledge could lead to better communication between physicians and patients." ${ }^{27}$ Promoting the willingness to process death information or education at school and in one's personal life can increase 
one's ability to cope emotionally and mentally with major health events such as illness or a pandemic.

Steele suggests we combat our current existential crises by mentalizing our fears. Educators can help to facilitate a "calm and deliberate task of trying to make sense of the mental states, beliefs, desires and fears that animate behavior in the self and others... we need calm discussions of our fears." ${ }^{28}$ The visuals in anime such as Cells at Work! can help viewers to perceive and mentalize fears about the body more easily. Because it is amusing entertainment that is visually pleasing, even when made up of images or scenes of horror, it could be a soft way to introduce hard topics to help set the stage for fruitful discussions and inquiries about health and death.

At its core, Cells at Work! is about the fragility of our bodies and dying a little at a time. This is an important concept to reinforce since we all too often "neglect the fragility of life... (even as) it is this fragility we must recognize and learn to live with, and to live within.”29 Death can become a less fearful concept if one can accept first that it is natural, normal, or even expected that we are vulnerable and fragile to the elements, environmental disasters, toxins, other organisms, and even each other. Fortunately, Cells at Work! also allows for the building of immunity and regeneration, ensuring that hope is always somewhere in residence. In the show's own story, the child platelets and young generation of rookie cells trying to find their way also give hope through their potential to heal. This hope is an important part of death education as it helps learners to combat existential fear. Ironically, "embracing our mortality can encourage hope."30

Anime may appear as fluff entertainment to some, but at the same time, "anime's storytelling makes it an intellectually challenging and stimulating art form that builds 
on high cultural traditions... anime is meant to be taken seriously." ${ }^{1}$ Viewers who are able to see beyond the bright colors, wide eyes, or big breasts that anime is so often associated with will be able to understand that anime can also deliver rich, complex stories and shine a light on pressing social issues, all while assigning life to things big and small.

Although primarily a light-hearted series, the implicit and hopeful message from Cells at Work! concerns how we must work together to overcome adversity and how caring for others, even if they have a different appearance or occupation, is a message that cannot be considered immature, low-brow, or unimportant. Cells at Work! cleverly teaches that every cell has a job/responsibility to itself and the cells around it, and that the actions we take or don't take eventually circulate back to us. Cells at Work! also reinforces the reality that we must work together in order to solve problems, and in particular, "when circumstances create common groups, terror management efforts can guide people to become more inclusive, cooperative, and peaceful." ${ }^{22}$ This is more important than ever to learn during a time of global pandemic. If viewers can see how their inner body is like a complex world on its own, with each section of the body like a state and each cell like an individual, then this may serve as inspiration towards acting on and modelling healthier behaviors on individual (micro) and societal (macro) levels.

\section{Implications for Well-being}

On top of being found in a beautiful art form with compelling storylines, anime and anime characters can also have positive psychological effects on viewers: "Peace of 
mind, being together with characters relaxes the spirit and can affect healing, first in a list of eight attributes, followed by: protection, escape from reality, regression, selfrealization, hope for transformation, health and activity, and mood changing." 33 Watching Cells at Work! can have uplifting emotional effects on viewers and simultaneously spread a positive message of communal responsibility. The speed at which we can affect each other either positively or negatively is apparent when we are living in the middle of a pandemic where the world is connected more than ever before, both physically and emotionally, because of high-speed transportation systems and high-speed Internet. How we act (or not) and what we say (or not) determines how quickly or slowly we can bring ourselves and each other to death. Edutainment with positive messages like Cells at Work! can give reminders that each individual has the power to make a difference in their own lives as well as other people's, and how being responsible for one's actions can contribute to the well-being of society.

Similar to how the number of casualties is tracked during world war, being bombarded by growing numbers of daily Covid-19 cases and death counts can chip away at our mortality salience, or awareness of death's inevitability. But easy-to-watch anime like Cells at Work! are capable of highlighting human vulnerability in an amusing and digestible way. By reinforcing and accepting the reality that no single body can ever be promised an average lifespan, perhaps we can start to ease or at least admit to a shared anxiety and dread of living in a "new normal" after almost two years lived with the daily reality of Covid-19. When death hits close to home, avoidance or denial of the topic may worsen or even prevent the ability to come to terms with that death, or else hinder one's ability to grieve in a healthy manner. Stories that parallel viewers' own real death stories 
could be a tool towards acceptance of loss, since "death in a fiction is an outlet to process one's own grief." 34 Building awareness of our mortality could also enable us to better work towards overcoming the pandemic: "The awareness of mortality can motivate people to enhance their physical health and prioritize growth-oriented goals; live up to positive standards and beliefs; build supportive relationships and encourage the development of peaceful, charitable communities; and foster open-minded and growthoriented behaviors.”35

Avoiding the fact that we are going to die will not make death stay away, and conversely, learning about death will not make us die earlier. However, learning about and coming to accept the reality of death someday could help create a better appreciation for life and relationships, and actually help prolong them. There is "potential for death thoughts to motivate healthy behaviors and attitudes... Importantly, conscious death awareness tends to motivate people to engage in these types of healthy behaviors... conscious thoughts of death can motivate efforts to reduce one's perceived vulnerabilities, potentially motivating behaviors and attitudes that improve one's physical health." ${ }^{6}$ Therefore, learning and reflecting on death gives reminders to take care of our own health and safety. This might cause a positive effect on one's peers and could even reverberate through a whole community, through the increasing awareness that everyone's health and safety are interconnected, much like the cells in Cells at Work!, who influence one another's well-being intimately as they all share the same environment. 


\section{Drawing Conclusions}

Cells at Work! is a reflection of the reality that death is an inevitable, constant, and ongoing process within the human body, and as a show it offers viewers glimpses into the workings and the dyings within our bodies that our naked eyes cannot see. Because the images and explanations of death in this show are entertaining, they are also easily digestible. They may provide a good avenue for young people to learn to understand and accept death not only in academics, such as when working with cadavers in biology class or when studying war in a humanities class, but also how death may play out in their personal lives. Cells at Work! shows that what we feel and do in the moment matters, that there are repercussions, and also that even if one feels like an insignificant cell in a large body, the choices and actions one does or does not make are significant enough to affect the whole. This is a light-hearted but still striking reflection of the fact that "all human beings are one interdependent species sharing the same planet. Recognizing that the coronavirus poses the same existential threat for all of us helps underscore that humanity is a group we all belong to. It's by working together and not turning on each other that we will be able to recover."37 Existential education coupled with a little light-hearted humor could help build the insight and empathy that we as human beings and always-dying creatures need, especially in times when we are easily overcome with fear, confusion, or desperation.

Cells at Work! effectively and visually reinforces how a human body is a complex network that must work together in order to survive and thrive, demonstrating how "when someone feels to be a part of a larger whole, the whole gains in significance while he or she, as a part, begins to see himself or herself as drawing significance from 
participation in that whole." 38 Participating for the greater good of a shared body/country/world can help boost the individual participant's confidence and wellbeing, as well as their understanding of their own significance, despite their being just a small part of a larger social body. This is the motivating factor for the cells in Cells at Work!, but it is also their way of managing terror and normalizing vulnerability together with the message that we need to continually seek help and work together in trying times. Cells at Work! does not pit man vs. man, but instead depicts (hu)man vs. ailment, an antagonist that viewers can all share an equal fear of, and something that could potentially put all of mankind on the same team if we could first work together to move forward from our core existential fears. 


\section{Endnotes}

${ }^{1}$ Takarajimansha, “Interview with Akane Shimizu," Konomanga.jp, November 2016, https://konomanga.jp/interview/83755-2.

2 Elena Samoylova, "The Mortal Code into the Multimedia Anime Phenomenon," International Multidisciplinary Scientific Conference on Social Sciences \& Arts SGEM, September 2014: 851, DOI: 10.5593/sgemsocial2014/B31/S11.111.

3 Kaori Mikama, "Demon Slayer: A Cultural Phenomenon for Pandemic Times," Nippon.com, February 4, 2021, https://www.nippon.com/en/in-depth/doo667/.

4 Maja Milcinski, "Impermanence and Death in Sino-Japanese Philosophical Context," Paideia:

Philosophy in Asia, August 1998, https://www.bu.edu/wcp/Papers/Asia/AsiaMilc.htm.

5 Debra J. Oochi, "Wobbly Aesthetics, Performance, and Message: Comparing Japanese Kyara with Their Anthropomorphic Forebears," Asian Ethnology 71, no. 1 (2012): 111,

http://www.jstor.org/stable/41551385.

${ }^{6}$ Maya Phillips, "The Upbeat Anime Cells at Work! is a Cure for Coronavirus Blues,"

Polygon.com, April 9, 2020,

https://www.polygon.com/2020/4/9/21215007/cells-at-work-best-anime-to-watch-netflix-crunchyrollcoronavirus.

7 Hannah Collins, "Watching this Anime Genuinely Makes You Smarter," CBR.com, August 25,2018, https://www.cbr.com/cells-at-work-anime-makes-you-smarter/.

8 Jason J. Wallin, "Putrid Deadagogies," in Problematizing Public Pedagogy, ed. Jake Burdick, Jennifer A. Sandlin and Michael P. O'Malley (London: Routledge, 2013): 41.

9 Ibid, 47.

${ }^{10}$ Todd May, Death: The Art of Living (London: Routledge, 2009): 80.

${ }^{11}$ Corissa Haury, "Cells at Work is a Surprisingly Educational and Amusing Anime," Ms. EnScene, July 31, 2018, http://msenscene.com/2018/o7/31/cells-at-work-is-a-surprisingly-educational-and-amusing-anime/. ${ }^{12}$ Stefan Bengston, "Death," in Dark Pedagogy: Education, Horror and the Anthropocene, edited by Jonas Andreasen Lysgaard and Martin Hauberg-Lund-Laugesen (London: Palgrave Macmillan, 2019): 78, https://doi.org/10.1007/978-3-030-19933-3_4.

${ }_{13}$ Mark Helmsing and Cathryn van Kessel, "Critical Corpse Studies: Engaging with Corporeality and Mortality in Curriculum." Taboo: Journal of Culture and Education 19, no. 3 (2020): 158, https://digitalscholarship.unlv.edu/taboo/vol19/iss3/10.

14 Julie Ruble and Kim Lysne, "The Animated Classroom: Using Japanese Anime to Engage and Motivate Students,” The English Journal 100, no 1 (2010): 37, www.jstor.org/stable/20787689.

15 Haury, "A Surprisingly Educational Anime."

${ }^{16}$ Collins, "Watching this Anime Genuinely Makes You Smarter."

${ }_{17}$ Peter Fobian, "I Asked a Med Student What He Thought About Cells at Work!"

Crunchyroll.com, February 2, 2018,

https://www.crunchyroll.com/anime-feature/2018/08/o2-1/i-asked-a-med-student-what-he-thoughtabout-cells-at-work.

${ }_{18}$ Raphael Motamayor, "Cells At Work! Will Teach You About Biology, With GratuitousViolence and an Overload of Cuteness," Slashfilm.com, March 3, 2020. https://www.slashfilm.com/cellsat-work/.

19 Jay Gibbs, "Why Cells at Work! Works,” Comicsverse.com, August 14, 2018, https://comicsverse.com/why-cells-at-work-works/.

20 Beatrice Viri, "Iyashikei: Let Anime's "Healing" Genre Soothe Your Pandemic Stress," CBR.com, November 25, 2020,

https://www.cbr.com/iyashikei-anime-healing-genre-soothe-pandemic-stress/.

${ }^{21}$ Interpret, "Anime Interest has been Surging Over the Last Year," Interpret: Digital

Entertainment, April 28, 2021.

https://interpret.la/anime-interest-has-been-surging-over-the-last-year/.

${ }^{22}$ Chieko Tsuneoka, “The World is Watching More Anime," The Wall Street Journal, November 14, 2020, 
https://www.wsj.com/articles/the-world-is-watching-more-animeand-streaming-services-are-buying11605365629.

${ }^{23}$ Sheldon Solomon, Jeff Greenberg, and Tom Pyszczynski. The Worm at the Core: On the Role of Death in Life (New York: Random House, 2015): 7.

24 Cathryn van Kessel, Kent den Heyer and Jeff Schimel, "Terror Management Theory and the Educational Situation,” Journal of Curriculum Studies 52, no. 3 (2020): 429, DOI:10.1080/00220272.2019.1659416.

25 Phillips, "The Upbeat Anime Cells at Work!"

${ }^{26}$ Kenneth E. Vail, Jacob Juhl, Jamie Arndt, Matthew Vess, Clay Routledge, and Bastiaan T. Rutjens, "When Death Is Good for Life: Considering the Positive Trajectories of Terror Management," Personality and Social Psychology Review 16, no. 4 (November 2012): 320,DOI: 10.1177/1088868312440046.

${ }_{27}$ Nick Valdez, "Scientists Praise Cells at Work! for its Entertaining Accuracy," Comicbook.com, August 26, 2018, https://comicbook.com/anime/news/cells-at-work-cancer-episode-accuracy-praised-anime.

${ }^{28}$ Howard Steele, "Covid 19: Fear and the Future: An Attachment Perspective," Clinical Neuropsychiatry 17, no. 2 (2020): 98, DOI:10.36131/CN20200213.

29 May, Death: The Art of Living, 85.

$3^{30}$ van Kessel, den Heyer and Schimel, "Terror Management Theory," 439.

${ }^{31}$ Ryan Fan, "Why is Anime so Universally Appealing?" Medium.com, November 10, 2019, https://ryanfan.medium.com/why-is-anime-so-universally-appealing-e6417527de8c.

$3^{2}$ Vail et al., "When Death is Good for Life," 314.

33 Hiroyuki Aihara, Characterizing Japan (Tokyo: Kodansha, 2007), quoted in Oochi, 111.

34 Tony Yao, "Processing Meaningful Death in Anime/Manga," Manga Therapy, February 20, 2021, https://www.mangatherapy.com/.

35 Vail et al., "When Death is Good for Life," 303.

${ }^{36}$ Vail et al., "When Death is Good for Life," 308.

37 Jeff Greenberg and Sheldon Solomon, "Coronavirus Reminds You of Death and Amplifies

Your Core Values, Both Bad and Good," The Conversation, May 21, 2020,

https://theconversation.com/coronavirus-reminds-you-of-death-and-amplifies-your-core-values- bothbad-and-good-137588.

${ }^{38}$ May, Death: The Art of Living, 91. 


\section{Bibliography}

Aihara, Hiroyuki. Characterizing Japan. Tokyo: Kodansha, 2007. Quoted in Debra J. Oochi,"Wobbly Aesthetics, Performance, and Message: Comparing Japanese Kyara with Their Anthropomorphic Forebears." Asian Ethnology 71, no. 1 (2012): 109-32.

https://asianethnology.org/downloads/ae/pdf/a1741.pdf.

Ancuta, Katarzyna. “Asian Gothic.” In Twenty-First-Century Gothic: An Edinburgh Companion, edited by Maisha Wester and Xavier Aldana Reyes, 249-262. Edinburgh: Edinburgh University Press, 2019.

Bengtsson, Stefan. "Death.” In Dark Pedagogy: Education, Horror and the Anthropocene, edited by Jonas Andreasen Lysgaard and Martin HaubergLund-Laugesen, 63-83. London: Palgrave Macmillan, 2019. https://doi.org/10.1007/978-3-030-19933-3_4.

Cells at Work! Directed by Kenichi Suzuki. Aniplex/Kodansha, Season 1, Episodes 1-13, Netflix, 2018. https://www.netflix.com/ca/title/81028791.

Collins, Hannah. "Watching This Anime Genuinely Makes You Smarter.” CBR.com, August 25, 2018. https://www.cbr.com/cells-at-work-anime-makes-you-smarter/.

Fan, Ryan. “Why Is Anime So Universally Appealing?” Medium.com, November 10, 2019. https://ryanfan.medium.com/why-is-anime-so-universally-appealinge6417527de8c.

Fobian, Peter. "I Asked a Med Student What He Thought About Cells at Work!" 
Crunchyroll.com, Feb 2, 2018.

https://www.crunchyroll.com/anime-feature/2018/o8/o2-1/i-asked-a-medstudent-what-he-thought-about-cells-at-work.

Gibbs, Jay. "Why Cells at Work Works.” Comicsverse.com, August 14, 2018.

https://comicsverse.com/why-cells-at-work-works/.

Greenberg, Jeff and Sheldon Solomon. "Coronavirus Reminds You of Death and

Amplifies Your Core Values, Both Bad and Good.” The Conversation, May 21, 2020. https://theconversation.com/coronavirus-reminds-you-of-death-andamplifies-your-core- values-both-bad-and-good-137588.

Haury, Corissa. "Cells at Work! is a Surprisingly Educational and Amusing Anime." Ms. EnScene, July 31, 2018.

http://msenscene.com/2018/o7/31/cells-at-work-is-a-surprisinglyeducational-and-amusing-anime/.

Helmsing, Mark and Cathryn van Kessel. "Critical Corpse Studies: Engaging with Corporeality and Mortality in Curriculum.” Taboo: Journal of Culture and Education 19, no. 3 (2020): 140-164. https://digitalscholarship.unlv.edu/taboo/vol19/iss3/10.

Interpret. “Anime Interest has been Surging Over the Last Year." Interpret: Digital Entertainment, April 28, 2021.

https://interpret.la/anime-interest-has-been-surging-over-thelast-year/.

May, Todd. Death: The Art of Living. Montreal: McGill University Press, 2009. 
Mikama, Kaori. “Demon Slayer: A Cultural Phenomenon for Pandemic Times.” Nippon.com,February 4, 2021. https://www.nippon.com/en/in-depth/doo667/.

Milcinski, Maja. "Impermanence and Death in Sino-Japanese Philosophical Context."Paideia: Philosophy in Asia, August 1998. https://www.bu.edu/wcp/Papers/Asia/AsiaMilc.htm.

Motamayor, Rafael. "Cells At Work! Will Teach You About Biology, With Gratuitous Violence and an Overload of Cuteness.” Slashfilm.com, March 3, 2020. https://www.slashfilm.com/cells-at-work/.

Occhi, Debra J. "Wobbly Aesthetics, Performance, and Message: Comparing Japanese Kyara with Their Anthropomorphic Forebears." Asian Ethnology 71, no. 1 (2012): 109-32. http://www.jstor.org/stable/41551385.

Phillips, Maya. "The Upbeat Anime Cells at Work! is a Cure for Coronavirus Blues." Polygon.com, April 9, 2020. https://www.polygon.com/2020/4/9/21215007/cellsat-work-best-anime-to-watch-netflix-crunchyroll-coronavirus.

Ruble, Julie and Kim Lysne. "The Animated Classroom: Using Japanese Anime to Engage and Motivate Students." The English Journal 100, no 1 (2010): 37-46. www.jstor.org/stable/20787689.

Samoylova, Elena. "The Mortal Code into the Multimedia Anime Phenomenon.”

International Multidisciplinary Scientific Conference on Social Sciences \& Arts SGEM, September 2014, 851-55. DOI: 10.5593/sgemsocial2014/B31/S11.111.

Solomon, Sheldon, Jeff Greenberg, and Tom Pyszczynski. The Worm at the Core: 
On the Role of Death in Life. New York: Random House, 2015.

Steele, Howard. "Covid-19, Fear and the Future: An Attachment Perspective."

Clinical Neuropsychiatry 17, no. 2 (April 2020): 97-99.

DOI:10.36131/CN2O200213.

Takarajimasha. "Interview with Akane Shimizu." Konomanga.jp, November 26, 2016. https://konomanga.jp/interview/83755-2.

Tsuneoka, Chieko. "The World is Watching More Anime.” The Wall Street Journal, November 14, 2020.

https://www.wsj.com/articles/the-world-is-watching-more-animeandstreaming-services- are-buying-11605365629.

Vail, Kenneth E., Jacob Juhl, Jamie Arndt, Matthew Vess, Clay Routledge, and Bastiaan T. Rutjens. "When Death Is Good for Life: Considering the Positive Trajectories of Terror Management.” Personality and Social Psychology Review 16, no. 4 (November 2012): 303-29. DOI: 10.1177/1088868312440046.

Valdez, Nick. "Scientists Praise Cells at Work! for its Entertaining Accuracy." Comicbook.com, August 26, 2018. https://comicbook.com/anime/news/cells-atwork-cancer-episode-accuracy-praised-anime/.

van Kessel, Cathryn, Kent den Heyer, and Jeff Schimel. “Terror Management Theory and the Educational Situation.” Journal of Curriculum Studies 52, no. 3 (2020): 428-442.

DOI:10.1080/00220272.2019.1659416.

Viri, Beatrice. “Iyashikei: Let Anime's 'Healing' Genre Soothe Your Pandemic Stress.” 
CBR.com, November 25, 2020. https://www.cbr.com/iyashikei-anime-healinggenre-soothe-pandemic-stress/.

Wallin, Jason J. “Putrid Deadagogies.” In Problematizing Public Pedagogy, edited by Jake Burdick, Jennifer A. Sandlin, and Michael P. O'Malley, 40-51. New York: Routledge, 2013.

Yao, Tony. "Processing Meaningful Death in Anime/Manga." Manga Therapy, February 20, 2021. https://www.mangatherapy.com/ 